\title{
New host and geographical record for Mooleptus rabuka (Nematoda: Gnathostomatidae) in the largenose catshark Apristurus nasutus (Carchariniformes: Scyliorhinidae) off Juan Fernández Archipelago, Chile
}

Nuevo hospedador y registro geográfico para Mooleptus rabuka (Nematoda: Gnathostomatidae) en el pejegato hocicón Apristurus nasutus (Carchariniformes: Scyliorhinidae) del Archipiélago Juan Fernández, Chile

\author{
Sara M. Rodríguez ${ }^{1}$, Guillermo D'Elía ${ }^{2}$ and Mario George-Nascimento ${ }^{3}$ \\ ${ }^{1}$ Programa de Doctorado en Biología Marina, Facultad de Ciencias, Universidad Austral de Chile, campus Isla Teja s/n, \\ Valdivia, Chile. s rodriz@yahoo.es \\ ${ }_{2}^{2}$ Instituto de Ciencias Ambientales y Evolutivas, Facultad de Ciencias, Universidad Austral de Chile, campus Isla Teja s/n, \\ Casilla 567, Valdivia, Chile \\ ${ }^{3}$ Departamento de Ecología, Facultad de Ciencias, Universidad Católica de la Santísima Concepción, Casilla 297, Concepción, \\ Chile
}

\begin{abstract}
The adult stage of the gnathostomatid nematode Mooleptus rabuka, is recorded for the first time from the stomach and intestine of the largenose catshark Apristurus nasutus, off Juan Fernández Archipelago, Chile. Morphology and morphometry showed small mild differences (i.e., body size, oesophagus length and caudal alae) when compared with specimens previously recorded at Japan. Possibly the host species and locality may have some effects on the nematode morphology.
\end{abstract}

Key words: Elasmobranch host, Metaleptus, new record, Southeastern Pacific Ocean

\section{INTRODUCTION}

Studies on the natural history of deep-sea Chondrichthyes heavily rely on incidental catches (Ando et al. 2002), consequently the knowledge is scarce in many aspects. Deep-sea parasitic fauna also remains poorly studied in several aspects, including the composition of parasite assemblages, geographic distribution, life cycles and host relationships (Rohde 2005). As such, when new deep-sea material is studied, new parasitic species from fishes (see Klimpel et al. 2001) and noteworthy new records of parasites (see Rodríguez et al. 2010) are often published.

Elasmobranchs in the southeastern Pacific Ocean are a highly diverse group, with at least 96 species reported off the coast of Chile, 53 of which are sharks (Lamilla \& Bustamante 2005). Among them, the largenose catshark Apristurus nasutus de Buen, 1959, and the brown catshark A. brunneus (Gilbert) (both Scyliorhinidae) are the only species in the genus reported from Chile (Lamilla \& Bustamante 2005, Andrade \& Pequeño 2008). These are deep-water catsharks known to inhabit continental slopes, trenches and submarine ridges at depths of 500-2000 $\mathrm{m}$ in all oceans except for polar seas (Nakaya 1975, Sato et al. 1999). Reports on parasites of elasmobranchs in Chile deal mainly with cestodes, and only 4 records exist on adult nematodes (see Muñoz \& Olmos 2008). The present study describes the nematodes found in the gut of $A$. nasutus and compares it with previous records.

\section{Materials ANd Methods}

Three pregnant females of the largenose shark Apristurus nasutus (total length: 570-592 $\mathrm{mm}$ ), were caught between 400-950 $\mathrm{m}$ deep in the submerged ridge off Juan Fernández Archipelago, southeastern Pacific Ocean, Chile, during April-May 2006. They were examined for endoparasites.

Nematodes collected were fixed and stored in $70 \%$ ethanol and cleared in lactophenol for examination. Drawings were made under a light microscope Hund Wetzlar H600 (40-1000x) and binocular dissecting scope Coleman (10-40x), both coupled with a camera lucida. One female and five male nematode specimens were examined 
under scanning electron microscopy (SEM) to reveal anatomical characteristics. Host taxonomy is in accordance with Compagno et al. (2005) and Lamilla \& Bustamante (2005). Measurements are in mm. Vouchers were deposited at the Museum of Zoology, Universidad de Concepción, Concepción, Chile (MZUC 34210 and MZUC 34211).

\section{Results AND Discussion}

Two of three largenose catshark Apristurus nasutus harboured the nematode Mooleptus rabuka Machida, Ogawa \& Okiyama, 1982, (prevalence 67\%, abundance 41.3 , range $0-100)$.

General description. Medium sized, brownish nematodes. Female larger than male. Body with thin cuticle with very fine transverse striations. Cephalic end rounded, mouth with two large lateral pseudolabia. Inner surface of pseudolabia somewhat trilobed in apical view, each lobe bearing small teeth, one larger situated medially and two small on either side. Four large submedian labial papillae situated at base of the pseudolabia near their margins; pair of lateral amphids present. Cephalic collarette absent. Two marked, rather wide lateral bands of hypodermal cells, extending along body. Oesophagus muscular with anterior end somewhat swollen, undivided. Ventriculus-like formation opening into intestine through distinct valve. Nerve ring encircling oesophagus approximately between anterior and middle thirds. Excretory pore and simple deirids at about same level, somewhat posterior to level of nerve ring. Intestine straight and dark brown in color only near its anterior end. Tail of both sexes conical, gradually tapering, with tip truncated. Reproductive system concentrated in short section of posterior part of body (Figs. 1 and 2).

\section{Male (SIX AdULt SPECIMENS, MEASUREMENTS IN TABLE 1)}

Ventral cloacal region extending to the middle of the tail. Nine pairs of papillae, one unpaired papilla and one pair of phasmids arranged as follows. Preanal papillae: three pairs of large, wide and equally spaced subventral papillae; one pair of small ventral papillae located just below the last pair of subventrals; and one large unpaired median papilla situated anterior to level of ventral papillae. Adanal papillae: one pair of small subventral papillae located on boths sides of the cloaca. Postanal papillae: one pair of small ventral papillae and three pairs of subventral papillae situated at the anterior half of the tail; of these last three, the second pair is situated more ventrally and is larger than the other two which are smaller. One pair of small lateral phasmids present near to end of the tail. Spicules equal in size (Fig. 1 and 2D-E).

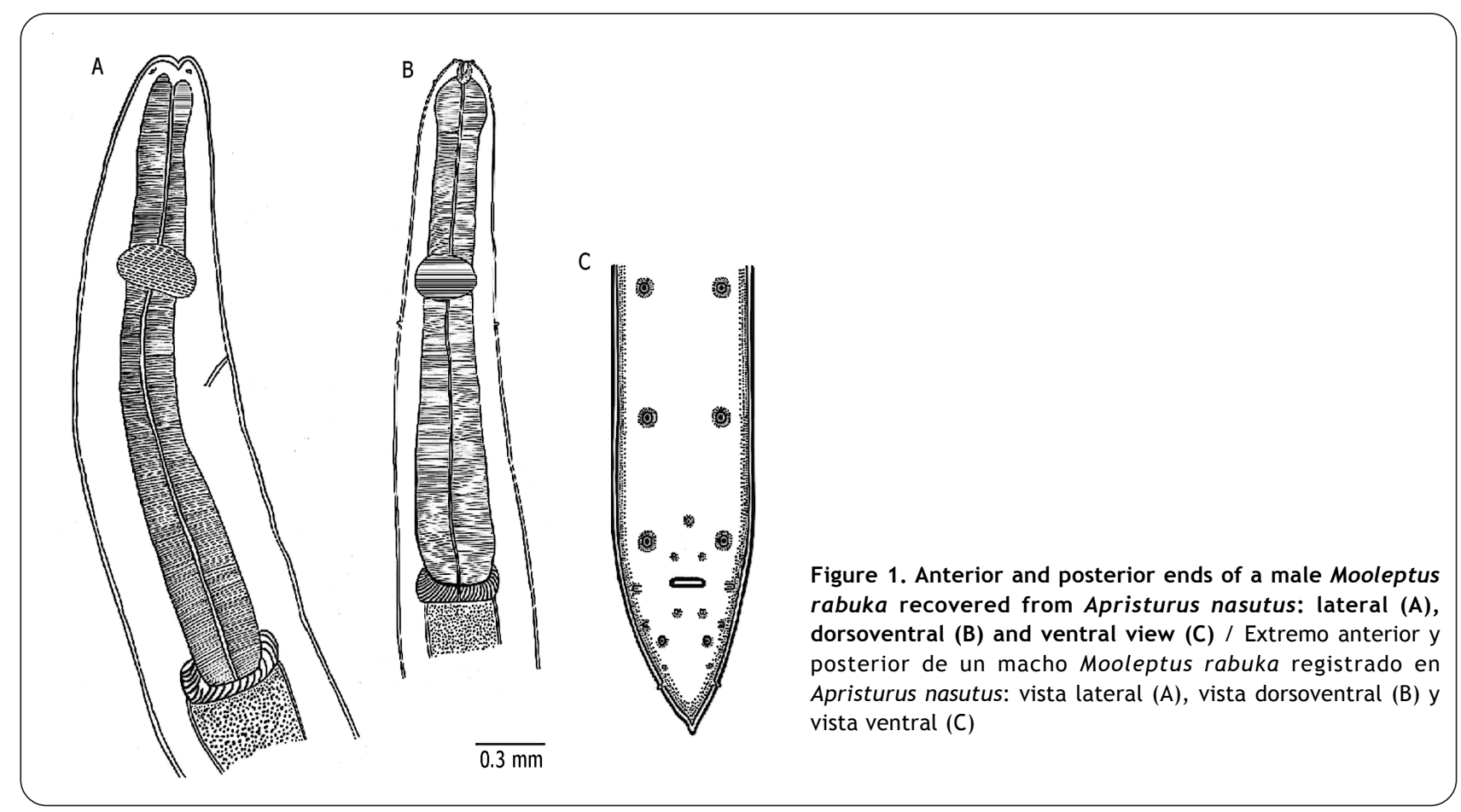


Female (SeVen Gravid SPECimens, measurements in TABle 1)

Vulva post-equatorial with vulval lips somewhat sclerotized. Muscular vagina directed first posteriorly and then anteriorly from vulva. Amphidelphic. Body at region of vulva conspicuously distended. Numerous eggs present at its distal region.

Morphology and morphometry of these nematodes fit fairly well within the ranges given by Machida et al. (1982) and Moravec \& Nagasawa (2000) for the description of Mooleptus rabuka (reported as Metaleptus) (Table 1). It is worth noting that the description of $M$. rabuka given in Machida et al. (1982) was incomplete and partly erroneous, because these authors did not mention that the nematode has a trilobed pseudolabia (Fig. 2A-B-C), although they did mention the presence of three bi or trifurcate teeth on the inner surface of each labium. Similarly, they recorded only 8 pairs of papillae in the male caudal end, but they did not provided any information about a large unpaired median preanal papilla (Fig. 2D-E). Possibly, they assessed the male caudal end only in lateral view which did not allow observing that feature. However, these characteristics were recorded by Moravec \& Nagasawa (2000) and in our study based on SEM micrographs.
On the other hand, our specimens differed in some morphology and morphometry with those collected at Japan (Table 1). For example, the specimens of the present study were slightly larger and with a larger oesophagus than specimens from Japan; and the caudal alae were not present in our sample. The biological meaning of these differences is difficult to clarify with the present data, but may be due to geographical variation or caused by the different host species (Apristurus fedorovi and $A$. japonicus for Japan, and Apristurus nasutus for Chile).

During the exploration of the parasitic helminth fauna of some marine fishes from Japan, Machida et al. (1982) described the new genus and species, Metaleptus rabuka a parasite of the deep-sea frill shark Chlamydoselachus anguineus Garman, 1884. These authors also found the larva presumed to belong to of $M$. rabuka in the brain of the deep-sea bristlemouth Cyclothone atraria Gilbert, 1905. In accordance with their cephalic structures and male caudal end, the species was placed originally in the family Physalopteridae Railliet, 1893. Later, Moravec \& Nagasawa (2000) recorded $M$. rabuka from the stomach of the deep-sea catshark Apristurus fedorovi Dolganov, 1983; while Ando et al. (2002) found it at the intestine of A. fedorovi and A. japonicus Nakaya, 1975 from the North Pacific Ocean off Honshu, Japan. Moravec \& Nagasawa

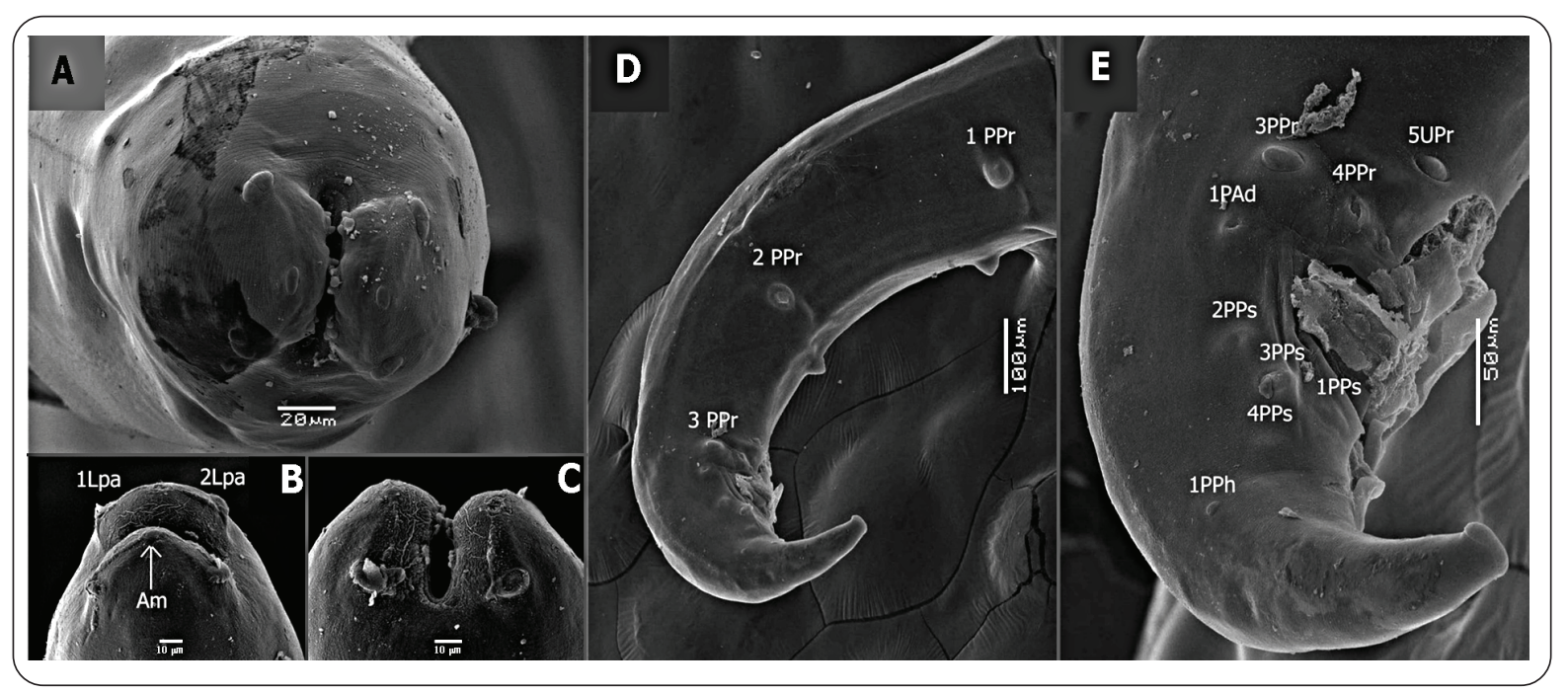

Figure 2. SEM micrographs of a male Mooleptus rabuka. Cephalic end: apical view (A), lateral view (B) (1-2 Lpa: Pair of lateral papillae; Am: Amphids) and dorsoventral view (C). Posterior end of male: lateral view (D) (1-2-3 PPr: Pair of preanal papillae) and detail of cloacal opening and anal papillae (E) (3-4 PPr: Pair of preanal papillae; 5 UPr: Unpaired preanal papilla; 1 PAd: Pair of adanal papillae; 1-2-3-4 PPs: Pair of postanal papillae; 1 PPh: Pair of phasmids) / Mooleptus rabuka. Fotomicrografía de microscopio electrónico de barrido del macho. Extremo cefálico: vista apical (A), vista lateral (B)(1-2 Lpa: Par de papilas laterales; Am: Anfidios) y vista dorsoventral (C). Extremo posterior del macho: vista lateral (D) (1-2-3 PPr: Par de papilas preanales) y detalle de la abertura cloacal, papilas anales (E) (3-4 PPr: Par de papilas preanales; 5 UPr: papila Preanal impar; 1 PAd: Par de papilas anales; 1-2-3-4 PPs: Par de papilas Postanales; 1 PPh: Par de phasmidos) 
Table 1. Measurements $(\mathrm{mm})$ of Mooleptus rabuka in the original description, from additional Japanese records and the sample reported in this study. $n=$ number of specimens measured. Machida et al. (1982) did not indicate number of female specimens / Medidas ( $\mathrm{mm}$ ) de Mooleptus rabuka presentadas en su descripción original, en registros adicionales de Japón y de la muestra reportada en este estudio. $\mathrm{n}=$ número de especímenes medidos. Machida et al. (1982) no indicaron el número de ejemplares hembras

\begin{tabular}{lcccccc}
\hline & \multicolumn{2}{c}{ Machida et al. $(1982)$} & \multicolumn{2}{c}{ Moravec \& Nagasawa (2000) } & \multicolumn{2}{c}{ This study } \\
& Male $(\mathrm{n}=4)$ & Female $(\mathrm{n}=?)$ & Male $(\mathrm{n}=5)$ & Female $(\mathrm{n}=5)$ & Male $(\mathrm{n}=6)$ & Female $(\mathrm{n}=7)$ \\
\hline Body length & $22.80-31.70$ & $29.00-33.90$ & $23.20-31.80$ & $28.60-33.50$ & $28.40-35.60$ & $27.80-39.00$ \\
Maximum width & $0.42-0.50$ & $0.67-0.92$ & $0.31-0.62$ & $0.87-1.11$ & $0.45-0.61$ & $0.55-0.91$ \\
Pseudolabia length & $\left.41-43 *^{*}\right)$ & $0.04-0.05$ & $0.02-0.05$ & $0.04-0.06$ & $0.03-0.05$ & $0.03-0.06$ \\
Pseudolabia width & - & - & $0.06-0.08$ & $0.08-0.14$ & $0.09-0.13$ & $0.10-0.14$ \\
Hipodermal bands width & - & - & 0.11 & $0.12-0.15$ & $0.04-0.15$ & $0.04-0.14$ \\
Oesophagus length & $1.85-2.08$ & $1.82-2.22$ & $1.67-2.04$ & $1.64-2.29$ & $1.23-1.70$ & $1.16-1.73$ \\
Oesophagus width & $0.20-0.22$ & $0.16-0.23$ & $1.17-0.22$ & $0.18-0.27$ & $0.17-0.26$ & $0.21-0.28$ \\
Nerve ring & $0.64-0.71$ & $0.67-0.74$ & $0.66-0.71$ & $0.69-0.71$ & $0.42-0.66$ & $0.46-0.68$ \\
Ventriculus-like formation length & $0.07-0.08$ & $0.08-0.13$ & $0.08-0.10$ & $0.08-0.10$ & $0.03-0.10$ & $0.05-0.06$ \\
Ventriculus-like formation width & - & - & $0.18-0.24$ & $0.19-0.27$ & $0.19-0.29$ & $0.21-0.25$ \\
Deirid & - & - & $0.89-1.03$ & $0.83-1.04$ & $0.54-0.97$ & $0.89-0.96$ \\
Spicules & $1.53-1.78$ & - & $1.52-1.77$ & - & $1.61-1.84$ & - \\
Tail & $0.28-0.36$ & $0.47-0.53$ & $0.38-0.47$ & $0.54-0.63$ & $0.46-0.59$ & $0.61-0.70$ \\
\hline
\end{tabular}

$(*)=$ Measurements expressed in $\mu$

(2000) and this study coincides that $M$. rabuka is characterized by the presence of a somewhat trilobed pseudolabia, an undivided oesophagus and 9 pairs of papillae and one unpaired median papilla on the male caudal end. In addition, the former authors transferred the monotypic genus Metaleptus was transferred from Superfamily Physalopteroidea Leiper, 1908, to Gnathostomatoidea Railliet, 1895, where the new subfamily Metaleptinae Moravec \& Nagasawa, 2000, was erected to accommodate it (Moravec \& Nagasawa 2000). Recently, and due to the fact that the name Metaleptus Machida et al. 1982 proved to be a homonym, having been preoccupied by Metaleptus Bates, 1872 (a genus of cerambycid beetles), Özdikmen (2010) re-named this nematodes genus as Mooleptus Özdikmen, 2010; consequently, the correct name of the type species is Mooleptus rabuka (Machida, Ogawa \& Okiyama, 1982) Özdikmen, 2010.

This report represents an extension of about 12.000 $\mathrm{km}$ of the known distribution of M. rabuka. The taxonomic enlargement derived from our records is not as noteworthy as it is in geographical terms. Adults of M. rabuka has been recorded from two species of Apristurus, and previous records already show the low specificity of this parasite presented in two shark families (Chlamydoselachidae and Scyliorhinidae) and larval stage in one Teleostei family
(Gonostomatidae). Remarkably, all hosts are deep sea fishes, a fact that signals on a component of the ecological niche of $M$. rabuka.

\section{ACKNOWLedgments}

We are deeply indebted with Claudio Carocca and Freddy Duarte for their assistance in collecting hosts and parasites. We thank two anonymous reviewers for their valuable suggestions. Financial support was partially provided by MECESUP AUS0805.

\section{Literature Cited}

Ando T, K Nagasawa \& K Nakaya. 2002. Stomach contents and nematode infection of two deep-water catsharks, Apristurus fedorovi and A. japonicus, from Northern Japan. Bulletin of Fisheries Science Hokkaido University 53: 4143.

Andrade I \& G Pequeño. 2008. Mesobathic chondrichthyes of the Juan Fernández seamounts: are they different from those of the central Chilean continental slope? Revista de Biología Tropical 56(1): 181-190.

Compagno LJV, M Dando \& S Fowler. 2005. Sharks of the world, 368 pp. Princeton University Press, Princeton and Oxford.

Klimpel S, A Seehagen, HW Palm \& A Rosenthal. 2001. Deep-water metazoan fish parasites of the world, $316 \mathrm{pp}$. Logos Verlag, Berlin. 
Lamilla J \& C Bustamante. 2005. Guía para el reconocimiento de tiburones, rayas y quimeras de Chile. Oceana 17: 1-80.

Machida M, K Ogawa \& M Okiyama. 1982. A new nematode (Spirurida, Physalopteridae) from frill shark of Japan. Bulletin of the Natural Science Museum, Tokyo, Serie A 8: $1-5$.

Moravec F \& K Nagasawa. 2000. Two remarkable nematodes from sharks in Japan. Journal of Natural History 34: 1-13.

Muñoz G \& V Olmos. 2008. Revisión bibliográfica de especies endoparásitas y hospedadoras de sistemas acuáticos de Chile. Revista de Biología Marina y Oceanografía 43: 173 245.

Nakaya K. 1975. Taxonomy, comparative anatomy and phylogeny of Japanese catsharks, Scyliorhinidae. Memoirs of the Faculty of Fisheries Hokkaido University 23(1): 194.
Özdikmen H. 2010. Substitute names for some Nematoda. Munis Entomology \& Zoology 5: 780-784.

Rodríguez SM, JL Luque \& M George-Nascimento. 2010. A parasitic copepod Neoalbionella sp. (Lernaeopodidae), on the southern laternshark Etmopterus granulosus (Etmopteridae) off the Juan Fernández Archipelago, Chile. Revista de Biología Marina y Oceanografía 45: 359-363.

Rohde K. 2005. Marine parasitology, 565 pp. CSIRO Publishing, Collingwood.

Sato K, K Nakaya \& AL Stewart. 1999. A new species of the deep-water catshark genus Apristurus from New Zealand waters (Chondrichthyes: Scyliorhinidae). Journal of the Royal Society of New Zealand 29: 325-335.

Received 19 August 2011 and accepted 31 January 2012 